Received 25.07.2016

Reviewed 03.08 .2016

Accepted 10.10.2016

A - study design

B - data collection

C - statistical analysis

D - data interpretation

$\mathbf{E}$ - manuscript preparation

F - literature search

\section{Degradation of water quality: the case of plain west of Annaba (northeast Algeria)}

\author{
Badra ATTOUI ${ }^{\mathrm{ABCDEF}}$, Nabila TOUMI ${ }^{\mathrm{ABE}}$, \\ Saloua MESSAOUDI ${ }^{\text {BF }}$, Samia BENRABAH ${ }^{\text {F }}$
}

Badji Mokhtar University of Annaba, Geological Laboratory, Route Sidi Amar, B.P. 12 Annaba, 2300, Algeria;

e-mail: att.badra@yahoo.fr, toumi_nabila@yahoo.fr, saloua_mess@yahoo.fr,hydroaanaba@hotmail.fr

For citation: Attoui B., Toumi N., Messaoudi S., Benrabah S. 2016. Degradation of water quality: the case of plain west of Annaba (northeast of Algeria). Journal of Water and Land Development. No. 31 p. 3-10. DOI: 10.1515/jwld2016-0031

\begin{abstract}
In the world, the water quality is undergoing deterioration due to urban and industrial wastes, and intensive use of chemical fertilizers in agriculture. Unfortunately, as in most countries of the world, Algeria is experiencing a severe crisis of its environment apart from the problem of depletion of water resources. The plain west of Annaba is particularly subjected to a general industrial pollution. The pollution problem in this region has really started to become worrying not earlier than in 1980, when the economic crisis has led some industrial units to sacrifice the "Environment" criterion for the benefit of the production. We were particularly interested in this work in waters of the superficial aquifer and wadis like Boudjemaa, Bouhdid, Sidi Harb, and Forcha whose waters are most often used to irrigate the surrounding agricultural land. Comparison of analytical results from two periods - 2006-2016 for the: $E C, \mathrm{pH}, \mathrm{Ca}^{2+}, \mathrm{Mg}^{2+}, \mathrm{Cl}^{-}, \mathrm{NO}_{2}$ and 2006-2010 for the: $\mathrm{Fe}, \mathrm{Cr}, \mathrm{Cu}^{2+}, \mathrm{Pb}^{+}$show a degradation of water quality in this region, which represents a very vulnerable area with a risk to pollution of groundwater.
\end{abstract}

Key words: degradation, plain - west of Annaba, pollution, water quality

\section{INTRODUCTION}

Water resource protection is one of the most essential concerns of any environmental policy, these resources being identified as paramount for the future. Account is taken of the use of these: Power catchments (drinking water, industrial, agricultural). A simplified diagram of water resource pollution scenario comprises a source of pollution (deposit leak discharge), a transfer process: a vertical migration in the soil and the subsoil to the aquifer (groundwater), a surface migration to a river (surface water) runoff for example. The target: water resources (food, swimming).

General context of the study area. The study area is limited to the north by the Mediterranean Sea to the west the massive Edough, south eastern $\mathrm{Nu}$ midian chain, to the east by the river Seybouse.

The geomorphology of the site is characterized by a flat topography across all the plain, marked by tilting bordering the plain, on the western and southern parts due to the anticline of metamorphic massif Edough, and Bellelieta, that the numidian chain. The geology of the property chain is composed mainly by primary base: to the west in the mountains of Jebel Edough, Bellelieta and Boukhadra, consisting of crystallophyllian rocks and Quaternary formation occupies the entire plain [MESSAOUdI, TOUMI 2006].

According hydrogeological cut (Fig. 2), two types of aquifers characterize the study area.

Superficial aquifer. It covers most of the plain of Kherraza. It extends over all the alluvial system of 


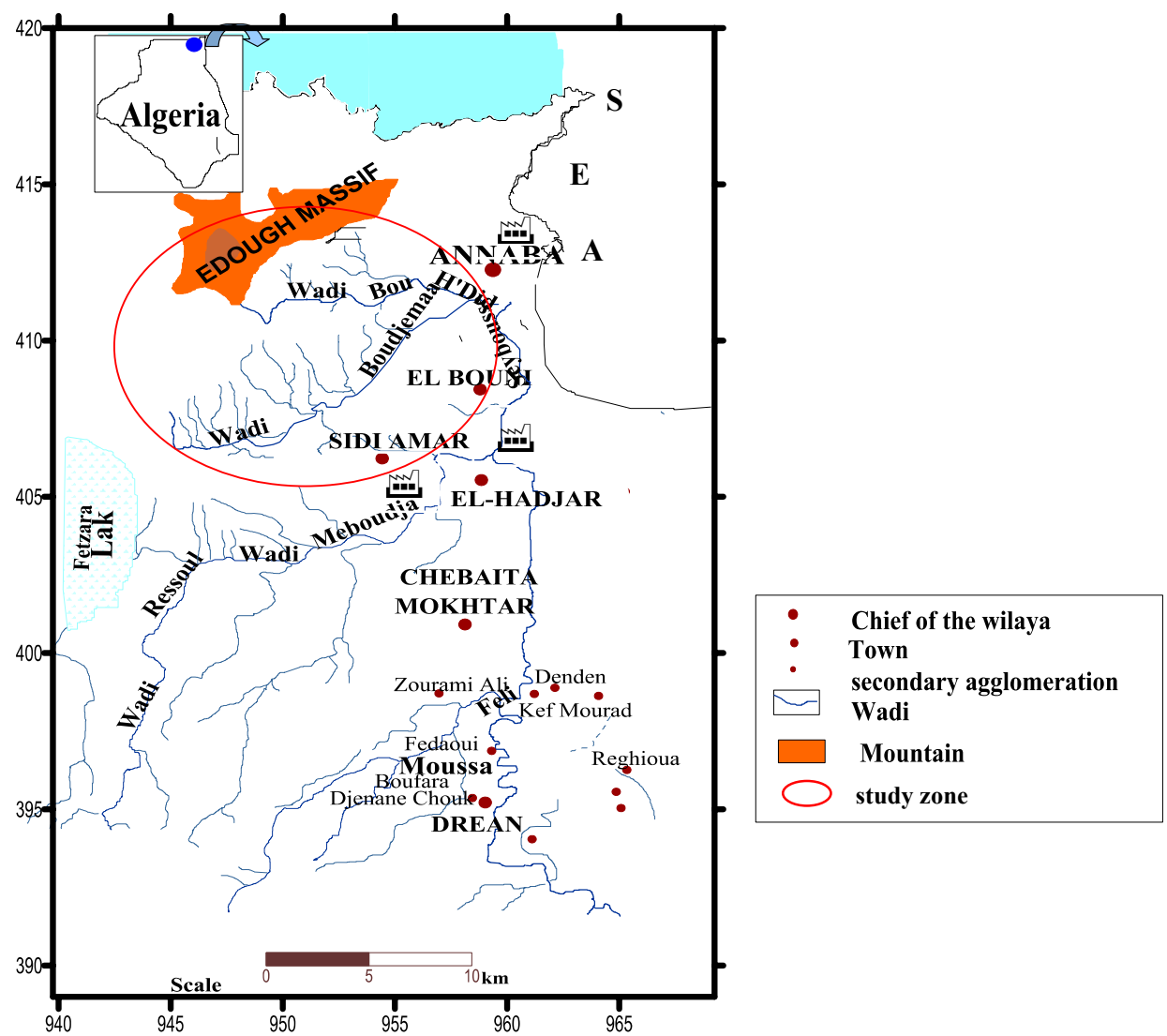

Fig. 1. Situation map of the study area [AтTOUI 2014]

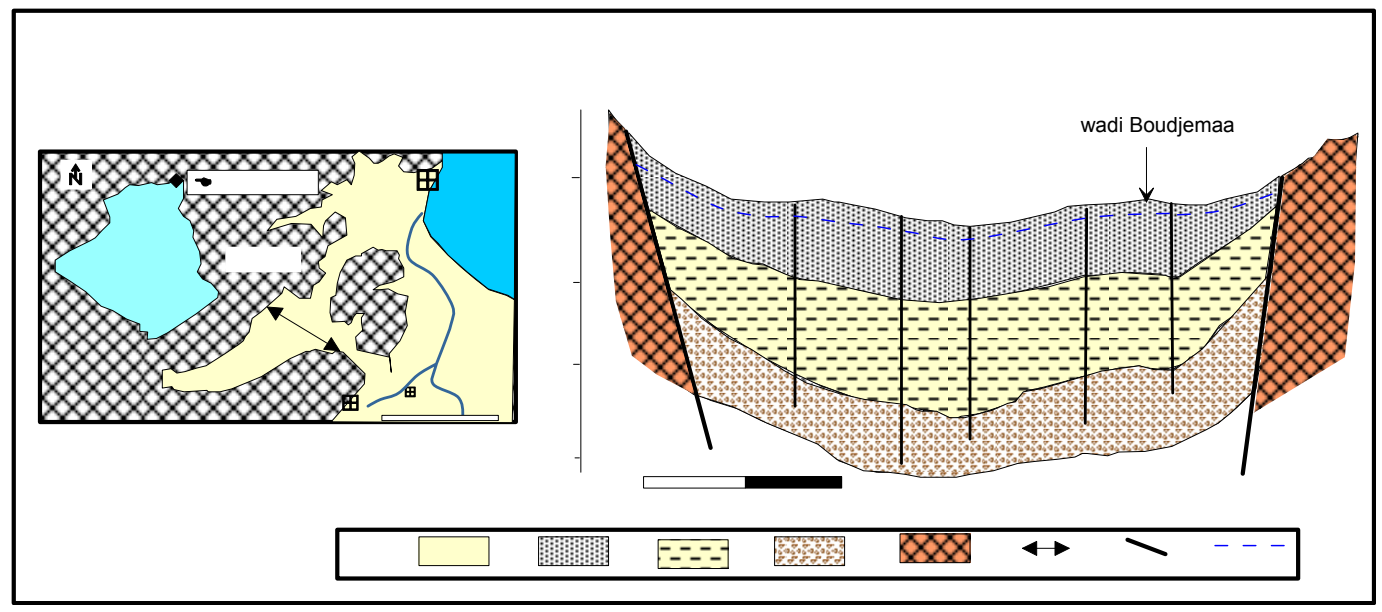

Fig. 2. Hydrogeological section through the study area; $1=$ undifferentiated quaternary, $2=$ old alluvial deposits, $3=$ clays, $4=$ conglomerates, gravel and cipolin, cracked gneiss, $5=$ metamorphic formations, $6=$ section, $7=$ fault, $8=$ piezometric level; source: MESSAOUDI, TOUMI [2016]

wadi Boujemaa. It is contained in recent and current alluvial with asandy clay and sandy liomeneuse texture, its thickness is about $10 \mathrm{~m}$; the water surface of this aquifer varies depending on precipitation, pumping and irrigation return [DEBIACHE 2002].

The deep aquifer. The depth of the majority of drilling done in the area is up to a maximum depth. It is surmounted by a clay layer with a thickness ranging from 15 to $25 \mathrm{~m}$. aquifer.
Lithologic of this aquifer is constituted firstly by training conglomeratic and gravelly resulting from alterations metamorphic formations [HANI et al. 2007], other hand to cipolin and gneiss heavily fissured.

The artisianisme of this aquifer can be explained by feeding in from the massive Edough and Bellelieta respectively located north and south of the plain of Kherraza, which has a network faille [KINIOUAR 2007], originally from cracking can the favored infiltration of surface water. 


\section{MATERIALS AND METHODS}

For the hydrochemical study, we have the results of the chemical analysis of 24 samples for water during the period (2006-2016) distributed as follows (Fig. 3):

6 samples in wadi Forcha,

4 samples in wadi Sidi Harb,
4 samples in wadi Bouhdid,

10 samples in wadi Boudjemaa.

And during the period (2006-2010), the hydrochemical study is carried out by 8 samples distributed as follows (Fig. 4):

2 samples in wadi Forcha,

2 samples in wadi Sidi Harb,

2 samples in wadi Bouhdid,

2 samples in wadi Boudjemaa.

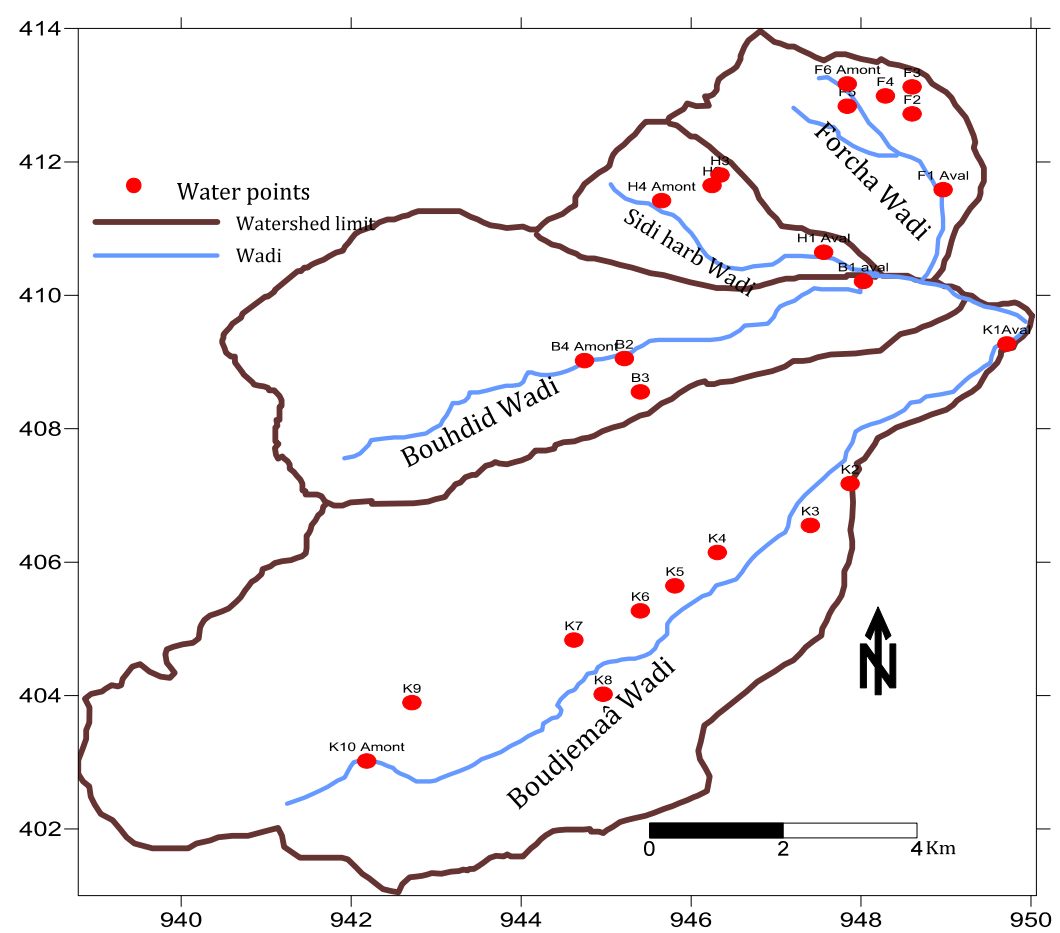

Fig. 3. Map inventory of water points in the region for the $E C, \mathrm{pH}, \mathrm{Ca}^{2+}, \mathrm{Mg}^{2+}, \mathrm{Cl}^{-}, \mathrm{NO}_{2}(2006-2016)$; source: own elaboration

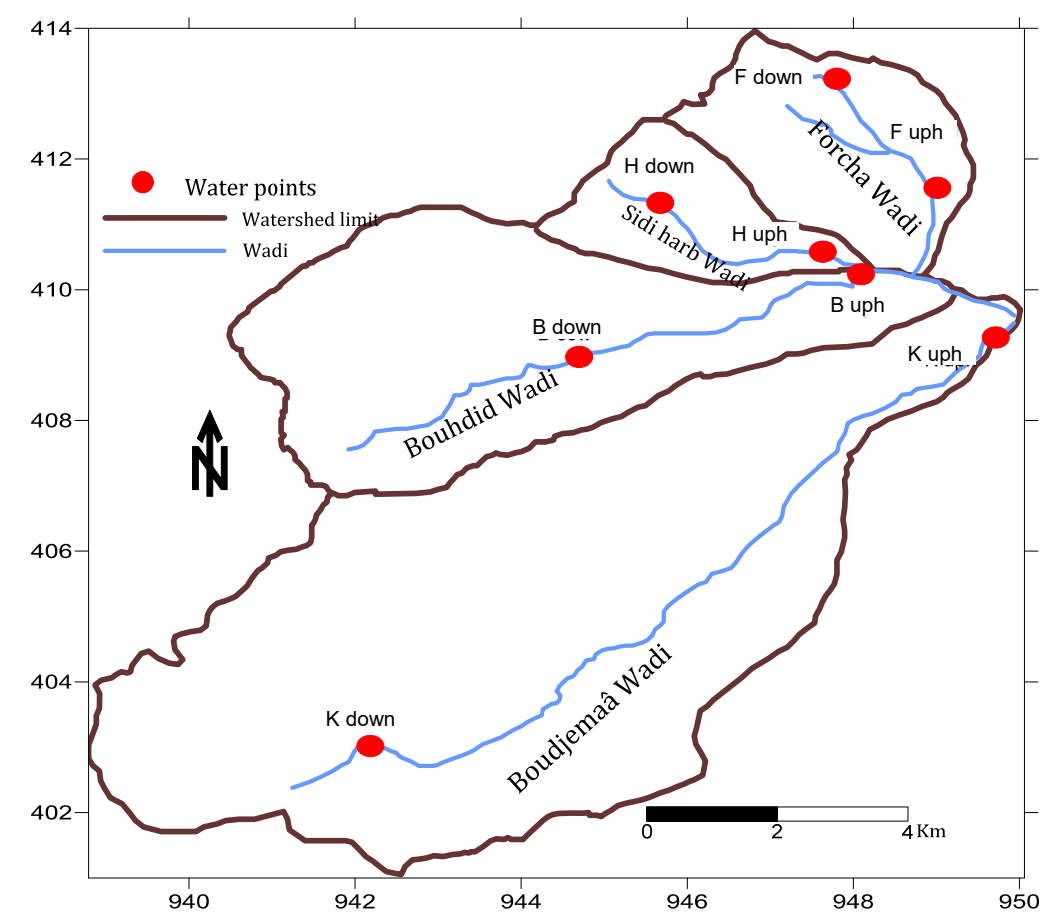

Fig. 4. Map inventory of water points in the region for the $\mathrm{Fe}, \mathrm{Cr}, \mathrm{Cu}^{2+}, \mathrm{Pb}^{+}(2006-2010)$; source: own elaboration 
The physicochemical parameters $T\left({ }^{\circ} \mathrm{C}\right), \mathrm{pH}, E C$ is measured in situ using two devices: a $\mathrm{pH}$ meter and a conductivity meter immediately after collection of the water sample.

The analysis of 24 samples for the following parameters:

- physical: $\mathrm{pH}, T\left({ }^{\circ} \mathrm{C}\right), E C$,

- chemicals: $\mathrm{Fe}, \mathrm{Cu}, \mathrm{Pb}, \mathrm{Cr}, \mathrm{Zn}, \mathrm{NO}_{2}, \mathrm{NO}_{3}, \mathrm{Ca}^{2+}$, $\mathrm{Mg}^{2+}, \mathrm{Cl}^{-}, \mathrm{K}^{+}, \mathrm{Na}^{+}$.

\section{RESULTAT AND DISCUSSION}

\section{THE ELECTRICAL CONDUCTIVITY}

The conductivity measurement allows rapidly devalue overall water mineralization and track the evolution in general. The conductivity increases progressively from upstream to downstream as follows river: 345 to $1370 \mu \mathrm{S} \cdot \mathrm{cm}^{-1}$ in 2006 and 260 to 1290 $\mu \mathrm{S} \cdot \mathrm{cm}^{-1}$ in 2016 .

These differences are due to rainy contributions which dilute the concentrations.

Generally the highest concentrations are found in all the plain of Kherraza in 2006 and the watershed of wadi Forcha in 2016 (Fig. 5).

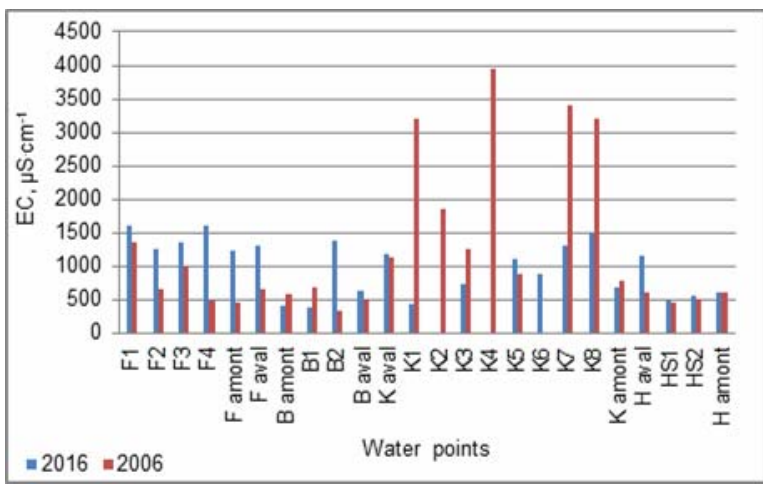

Fig. 5. Variation of the electrical conductivity $E C$ in the study area (2006-2016); water points as at Fig. 3; source: own study

\section{THE $\mathbf{p H}$}

It is a parameter that determines the acidity or alkalinity of water and a of equilibrium state of chemical elements.
The histogram shows that the waters of points are in the range of potability standard but has varying values.

In 2006 and at the four wadis (Forcha, Sidi Harb, Bouhdid and Kherraza) the $\mathrm{pH}$ between 7 and 8, this is due to direct contact with air to the wadis and because of the absence of acidic inputs or for alkaline groundwater (wells). By against $\mathrm{pH}$ values in 2016 vary between 5.8 and 8 , it is not very variable with respect to that of 2006 (Fig. 6). This expresses the variation and increase of the anionic and cationic exchange. It is a parameter that determines the acidity or alkalinity of water and a of equilibrium state of chemical elements. The histogram shows that the waters of points are in the range of potability standard but has varying values.

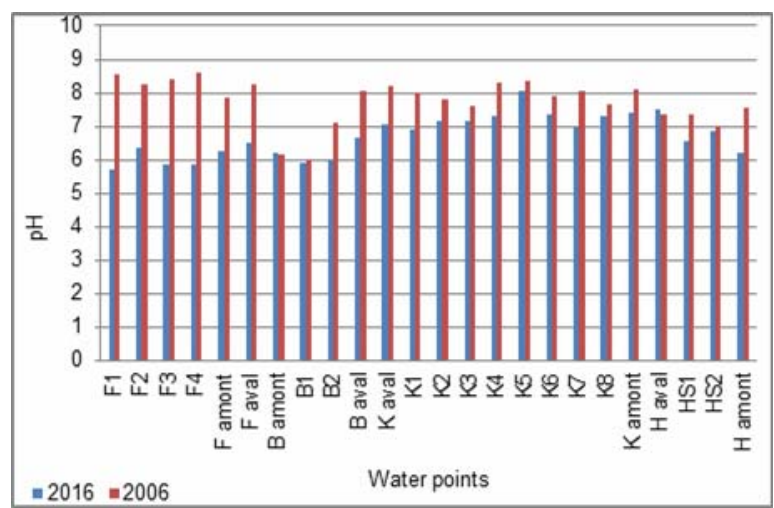

Fig. 6. pH variation in the study area (2006-2016); water points as at Fig. 3; source: own study

\section{THE CALCIUM $\left(\mathrm{Ca}^{2+}\right)$}

The presence of $\mathrm{Ca}^{2+}$ ions in water is generally due to the dissolution of gypsum formations $\left(\mathrm{CaSO}_{2}\right)$. According the maps concentrations of $\mathrm{Ca}^{2+}$ the high levels that exceed the standards are observed mainly in the plain of Kherraza. These levels vary between 40 and $360 \mathrm{mg} \cdot \mathrm{dm}^{-3}$ in 2006 and from 16 to 1033 $\mathrm{mg} \cdot \mathrm{dm}^{-3}$ in 2016 . On the edge of wadi Forcha, the levels vary between 24 and $232 \mathrm{mg} \cdot \mathrm{dm}^{-3}$ in 2006 and $16-337 \mathrm{mg} \cdot \mathrm{dm}^{-3}$ in 2016 which can be explained by the proximity of metamorphic formations (cipolin: rich in calcite $\mathrm{CaCO}_{3}$ ) [DJABRI 1996].

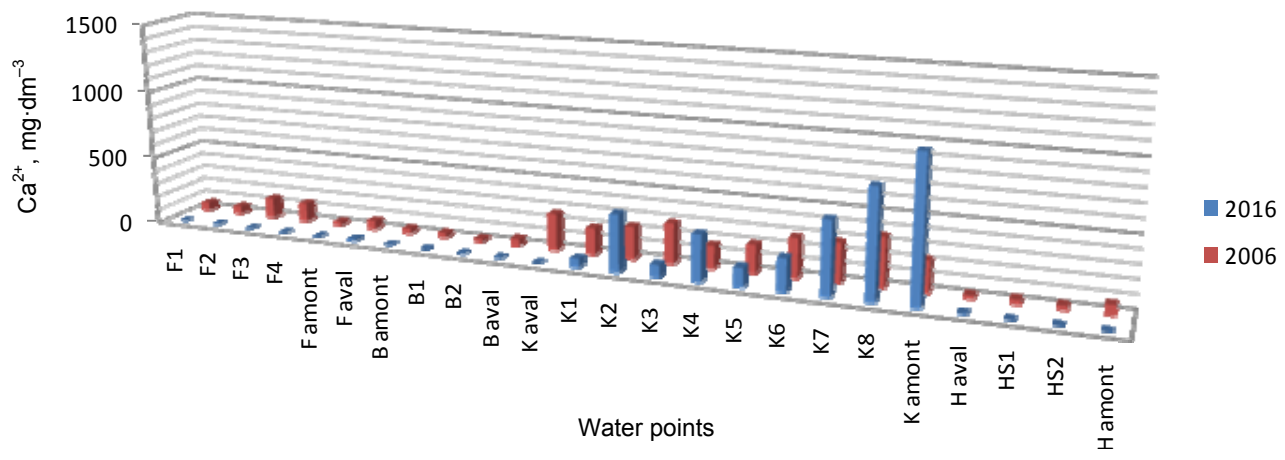

Fig. 7. Variation of the calcium concentration (standard $\left.=100 \mathrm{mg} \cdot \mathrm{dm}^{-3}\right)(2006-2016)$; water points as at Fig. 3; source: own study 
According to the above histogram (Fig. 7) usually a large increase in $\mathrm{Ca}^{2+}$ due to agricultural activities are observed (fertilizers) to the plains of Kherraza or because metamorphic formations that are flush in the Forcha River, and the evolution the $\mathrm{pH}$ which plays a very important role of ion exchange [HANI et al. 2002].

\section{MAGNESIUM $\left(\mathrm{Mg}^{2+}\right)$}

Its origins are comparable to that of calcium, because it comes from the dissolution of carbonate formations with high contents of $\mathrm{Mg}^{2+}$ (magnesite and dolomite).
Comparison of concentrations with standards shows that the highest levels are observed at the level of Kherraza plain and bordering the wadi Forcha, they are greater than $28 \mathrm{mg} \cdot \mathrm{dm}^{-3}$ and can reach $68 \mathrm{mg} \cdot \mathrm{dm}^{-3}$ in 2006 (Fig. 8) and $24 \mathrm{mg} \cdot \mathrm{dm}^{-3}$ to $240 \mathrm{mg} \cdot \mathrm{dm}^{-3}$ in 2016 for watersheds of wadi Sidi Harb and wadi Bouhdid and the contents are lower in both periods 2006 and 2016.

The histogram (Fig. 8) shows a progressive increase in the concentration of this element and most remarkable at the level of Kherraza plain essentially due to several factors.

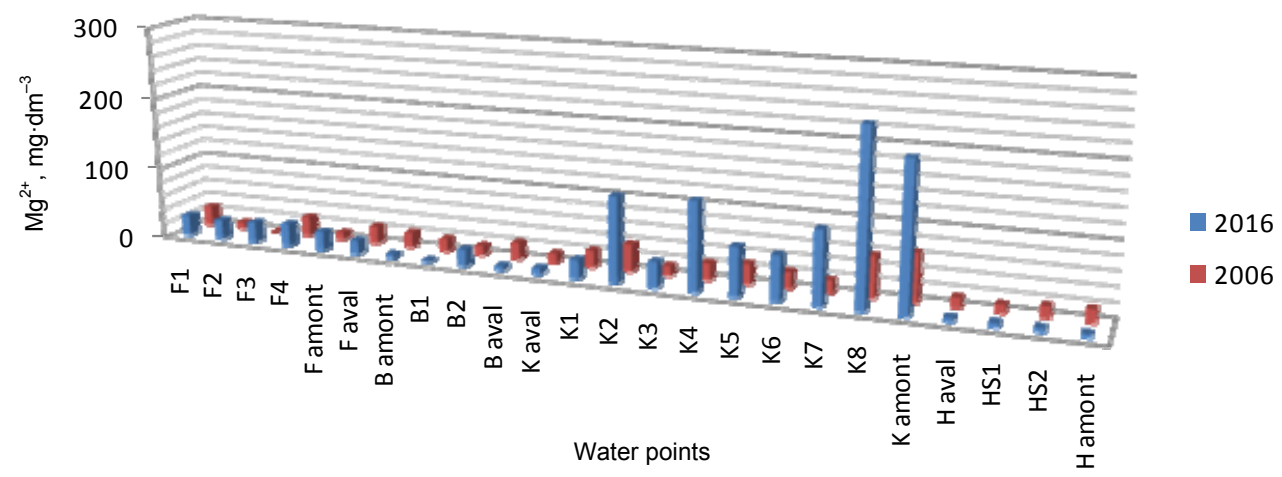

Fig. 8. Variation of the magnesium concentration (2006-2016); water points as at Fig. 3; source: own study

\section{CHLORIDES $\left(\mathrm{Cl}^{-}\right)$}

The origin of this element is mainly related to the dissolution of salt-bearing minerals [BRGM 2000]. In groundwater of the plain Kherraza the concentrations are highly variable; they pass 70 to 916 $\mathrm{mg} \cdot \mathrm{dm}^{-3}$ in 2006 and 6 to $76.8 \mathrm{mg} \cdot \mathrm{dm}^{-3}$ in 2016 . By against they can be more important 670 and 916 $\mathrm{mg} \cdot \mathrm{dm}^{-3}$ in 2006 and 3 to $60 \mathrm{mg} \cdot \mathrm{dm}^{-3}$ in 2016 at some points to the upstream of wadi Forcha and wadi Bouhdid.

By against are less than $300 \mathrm{mg} \cdot \mathrm{dm}^{-3}$ in 2006 and $33 \mathrm{mg} \cdot \mathrm{dm}^{-3}$ in 2016 in the sampling points in the Sidi Harb sector (Fig. 9). Very important and we notice a degradation a remarkable allows us to will open a hydro-chemical investigation of this apparent.

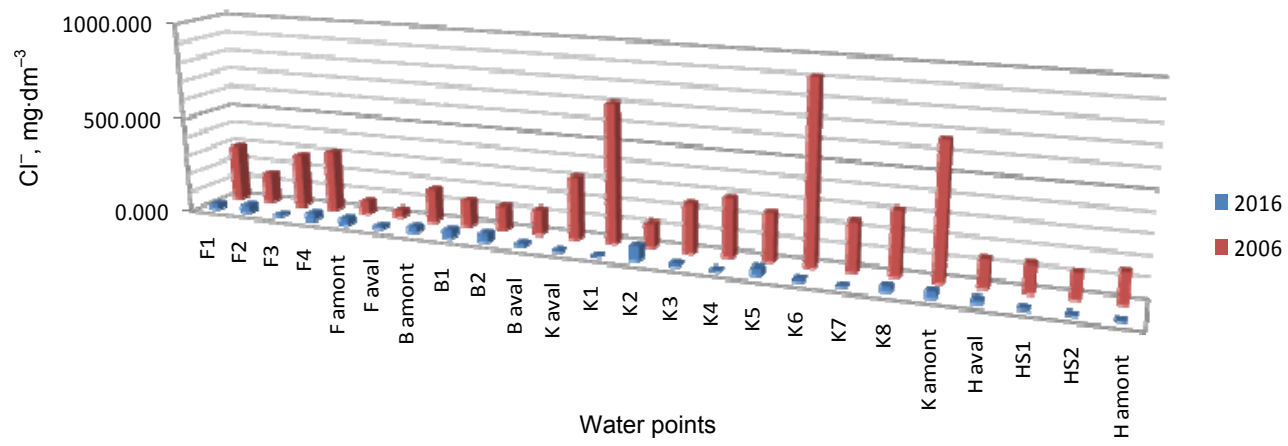

Fig. 9. Variation of the chloride concentration (2006-2016); water points as at Fig. 3; source: own study

\section{THE NITRITE}

Represents a less oxygenated form and less stable, it is a form that shows the transition between nitrate and ammonium, it is very toxic [ALLOWAY 1995; LIONS 2004]. The highest values were observed at the downstream of the wadis: Forcha, Sidi Harb and Bouhdid are concentrations varies between $0.2-32$ $\mathrm{mg} \cdot \mathrm{dm}^{-3}$ and $0-65 \mathrm{mg} \cdot \mathrm{dm}^{-3}$ in all the plain of Kherraza, these values are exceeded standards, then be can say that the study area is largely polluted by nitrites and highly contaminated in the endorsements of four watersheds (Fig. 10).

The high concentrations of nitrites are due to the use of fertilizers in the plain of Kherraza and urban discharges in other watersheds. 


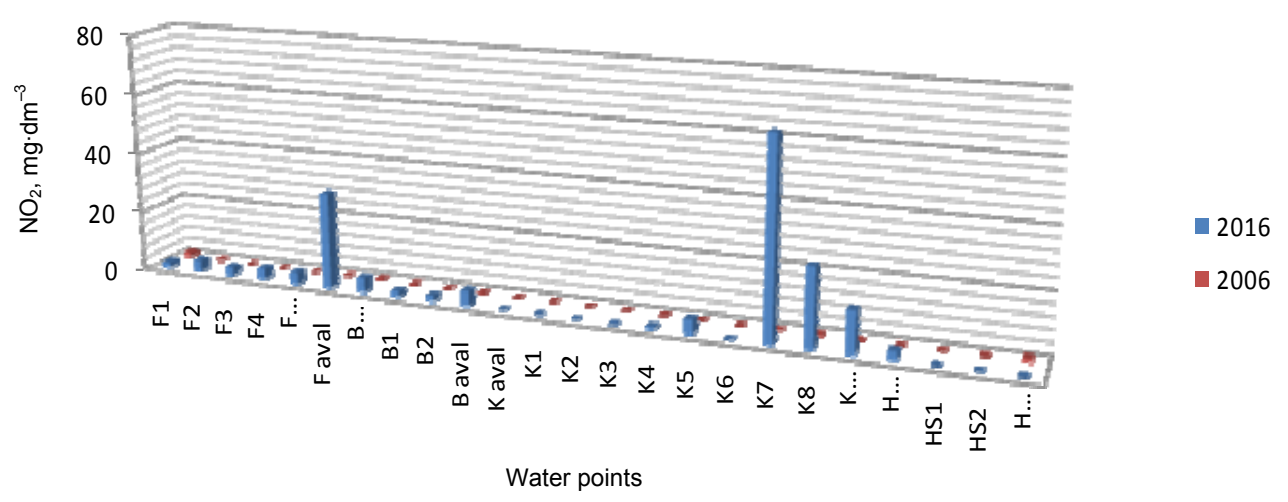

Fig. 10. Variation of the nitrite concentration (2010-2006); water points as at Fig. 4; source: own study

\section{TOTAL IRON}

The presence of iron in the water can have various natural origins by leaching of clay soils. In wellaerated water, concentrations of this element are strong range from 0 to $4.6 \mathrm{mg} \cdot \mathrm{dm}^{-3}$ in 2006 and 0.2 to
$1.5 \mathrm{mg} \cdot \mathrm{dm}^{-3}$ in 2010 between downstream and upstream of each watershed (Fig. 11). In general, the values exceeds the standards. The presence of this element is related to the reduced character of water that promotes the release of this element.

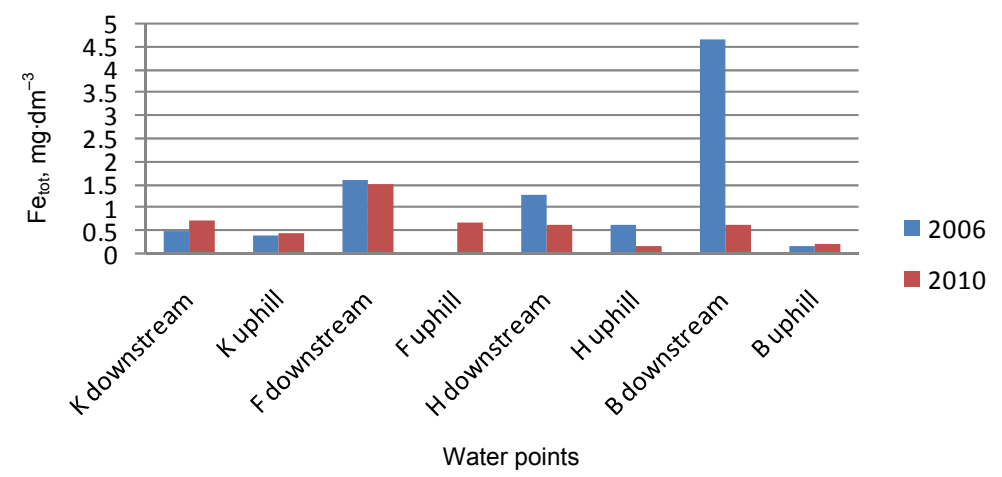

Fig. 11. Variation of the total iron $\left(\mathrm{Fe}_{\mathrm{tot}}\right)$ concentration (2006-2016); water points as at Fig. 4; source: own study

\section{THE CHROME}

In nature, the chromium is in the basic rocks with larger concentrations and in traces in silicates. In the study area the chromium concentration depends on the nature of the geological formations. We find the highest concentrations in West Plain level of
Annaba (wadi Forcha, wadi Sidi Harb and wadi Bouhdid) that does not exceed $0.1 \mathrm{mg} \cdot \mathrm{dm}^{-3}$ or in 2006 or in 2010 against the low levels are observed in the plains Kherraza (levels below $0.03 \mathrm{mg} \cdot \mathrm{dm}^{-3}$ in 2006 and 0.04 in 2010) (Fig. 12). They are related to the effect of urban waste and the effect of stagnant water in the wadi [MAJOUR 2010].

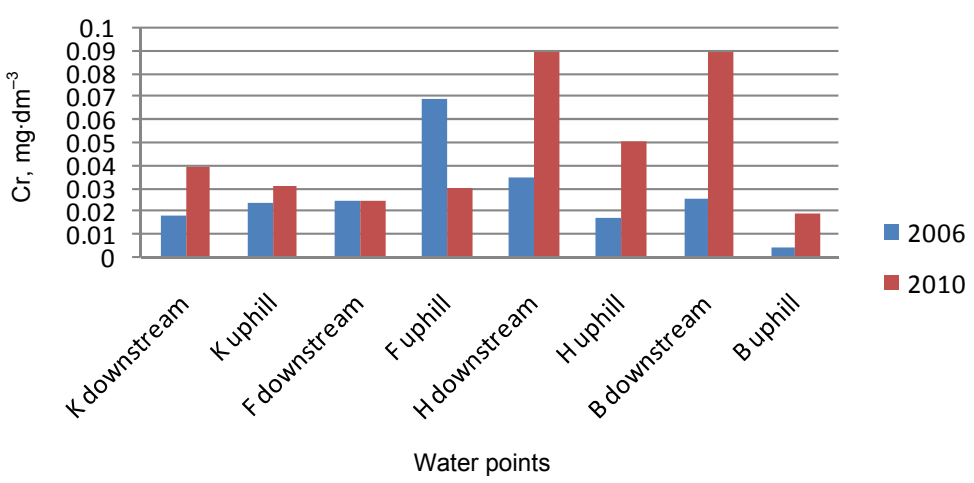

Fig. 12. Variation of the chromium concentration (2006-2010); water points as at Fig. 4; source: own study 


\section{THE COPPER}

Copper is present in nature in the form of native copper ores, or oxidized sulfide ores. In the study area the concentrations are very low $\left(<0.03 \mathrm{mg} \cdot \mathrm{dm}^{-3}\right)$ in 2006. They are below the potability norm of surface water and irrigation water by against are most remarkable in 2010 it can reach $0.27 \mathrm{mg} \cdot \mathrm{dm}^{-3}$ (Fig. 13). The relative increase in copper in the water course of the waters can be attributed to anthropogenic con- tamination due to emissions [REMITA 2008]. That empty into water courses. (The copper is entering into the composition of many alloys [MAJOUR 2010]).

Should be noted that the high $\mathrm{Cu}$ concentrations are toxic to fish, aquatic life by against can be disrupted by lower doses, but the conditions of toxicity vary according to species and the composition of the water (dissolved oxygen, dioxide carbonic, temperature, calcium, magnesium etc.).

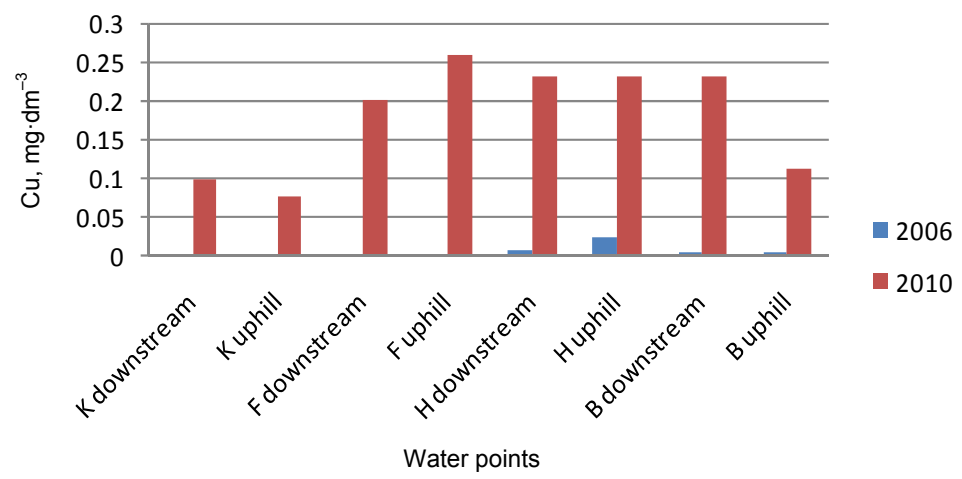

Fig. 13. Variation of the copper concentration (2006-2010); water points as at Fig. 4; source: own study

\section{THE LEAD}

Lead is in the manufacture of solder pigments, it is found in the form of sulfides, phosphates and carbonates. The low concentrations are observed in the plain of Kherraza vary between 0 and $0.46 \mathrm{mg} \cdot \mathrm{dm}^{-3}$ in 2006 and 0.2 to $1.2 \mathrm{mg} \cdot \mathrm{dm}^{-3}$ in 2010 (Fig. 14). The high concentrations were observed at the Basin of wadi Forcha of period high water from 0.1 to 0.9 $\mathrm{mg} \cdot \mathrm{dm}^{-3}$ in 2006 and at wadi Bouhdid and wadi Sidi Harb and 0.2 to $1.2 \mathrm{mg} \cdot \mathrm{dm}^{-3}$ in 2010 . Generally a significant increase of this element in the study area is observed [SABOUA 2010].

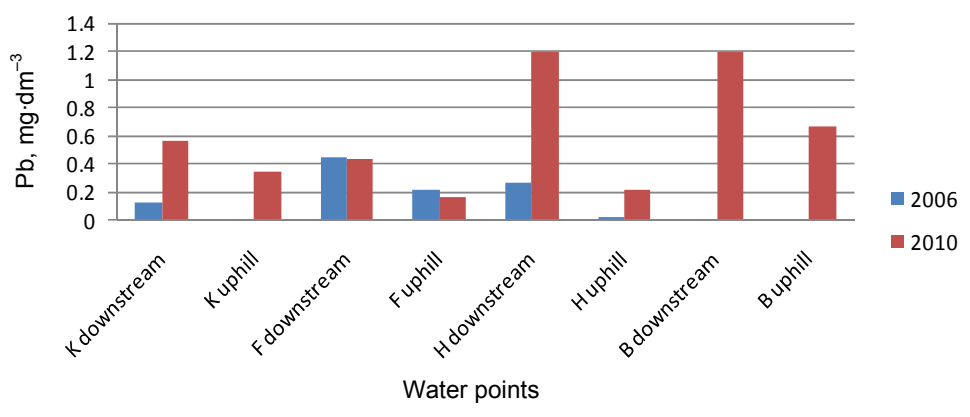

Fig. 14. Variation of the lead concentration (2006-2010); water points as at Fig. 4; source: own study

\section{CONCLUSIONS}

Increasing populations and intense agricultural and industrial activity have caused serious pollution of the environment and waters which has caused environmental degradation in the Annaba region.

At the west plain of Annaba, including plain Kherraza surface and groundwater in this region are often used to meet the water needs for irrigation and people's needs.

Three main activities occupy the soil of the region: the agricultural land extending over most of the surface of the plain Kherraza from the western plain, rather occupied dwellings. In addition, the industrial zones are located mainly on the banks of wadis Forcha, Sidi Harb, Bouhdid and Boudjemaa. The main sources of pollution are represented by direct discharges of urban waste water and fertilizers used in agriculture.

Discharges of urban waste water are represented by those agglomerations that occupy the majority of the western lowland area.

In agricultural areas fertilizers are deposited directly on the floor posing a major risk to the water quality of the water, with the possibility of alteration and training of this product by the effect of rain by infiltration to groundwater. 


\section{REFERENCES}

ALlowAY B.J. 1995. The mobilization of trace elements in soils. In: Contaminated soils: 3rd International Conference on the Biogeochemistry of Trace Elements, Paris (France), May 15-19, 1995. Proceeding. Ed. R. Prost. Paris. INRA p. 133-145.

AtToui B. 2014. Etat de la vulnérabilité à la pollution des eaux des grands réservoirs d'eaux souterraines de la région de Annaba - El-Tarf et identification des sites d'enfouissement de déchets [State of the vulnerability of water pollution from large reservoirs of groundwater in the region of Annaba and El-Tarf identification of landfill sites]. PhD Thesis pp. 172.

BRGM, methodological 2000. Guide: Site management (potentially) polluted Technical Report. Orleáns.

DeBIECHE T.H. 2002. Evolution de la qualité des eaux (salinité, azote et métaux lourds) sous l'effet de la pollution saline, agricole et industrielle [Evolution of water quality (salinity, nitrogen and metalsheavy) due to salt pollution, agricultural and industrial]. Application to low plain of the Algerian Seybouse Northeast. PhD. Thesis. Univ. Franche-Comté pp. 235.

DJABRI L. 1996. Mécanismes de la pollution et vulnérabilité des eaux de la Seybouse Origine géologiques, industrielles, agricoles et urbaine [Pollution mechanism and vulnerability of waters Seybouse, geological origins, industrielles, agricultural and urbaines]. PhD Thesis. Annaba Univ. pp. 200.

Hani A., DJabri L., Mania J., Majour H. 2002. Evolution des caractéristiques physico-chimiques des eaux souterraines du massif cristallophyllien de l'Edough (Annaba, Algerie) [Evolution of the physicochemical characteristics of groundwater of massive crystallophyllian of Edough] (Annaba, Algeria). 19th African geology symposium, El Jaddida (Morocco) pp. 100.

HANI A., DJorfi S., DJABRi L., LAMOUROUX C., LALlahEM S. 2007. Impact of the industrial rejection on water aq- uifer of Annaba (Algeria). European Water. Iss. 19/20 p. $3-14$.

LiONS J. 2004. Etude hydrogéochimique de la mobilité de polluants inorganiques dans des sédiments de curage mis en dépôt. Expérimentations, étude in situ et modelisations [Hydrogeological study of the mobility of inorganic pollutants in the repository layout dredged sediment (experimentation, in situ and modeling)]. $\mathrm{PhD}$ Thesis. Paris. National School of Mines of Paris Suparieur pp. 100.

KINIOUAR M.B. 2007. Mise à jour des connaissances sur les éléments biologiques et persistants des minéraux dans les boues des eaux usées des stations de traitement. Impact sur la santé publique [Update of knowledge of the biological and persistent mineral elements in the sludge of wastewater treatment plants]. Impact on public health. Maisons - Alfort. École nationale vétérinaire d'Alfort pp. 147.

MAJOUR H. 2010. Qualité des eaux du massif de l'Edough et de son piedmont sud «Berrahal»: apport des éléments majeurs et traces dans l'identification d'une pollution industrielle [Quality of the waters of the Edough massif and its southern piedmont «Berrahal»: contribution of the major elements and traces in the identification of an industrial pollution]. $\mathrm{PhD}$ Thesis pp. 135.

Messaoudi I.S., Toumi N. 2006. Impact des rejets urbains sur l'environnement dans la plaine ouest Annaba [Impact of urban discharges on the environment if the west plain of Annaba]. Ingéniorat memory pp. 60.

Remita A. 2008. Remmobilisation des métaux dans les eaux de l'Oued Boudjemâa et ses affluents [Immobilization of metals in the waters of Oued Boudjemaa and its tributaries]. These of magister. Annaba Univ. pp. 126.

SABOUA T. 2010. Origines de la pollution hydrique et atmosphérique dans la plaine Ouest de la région d'Annaba [The origin of the water and air pollution in the plain west of D'Annaba region]. These of magister. Annaba Univ. pp. 95.

\section{Badra ATTOUI, Nabila TOUMI, Saloua MESSAOUDI, Samia BENRABAH}

\section{Pogorszenie jakości wody: przykład równiny na zachód od Annaby w północno-wschodniej Algierii}

\section{STRESZCZENIE}

Pod wpływem ścieków miejskich i przemysłowych oraz intensywnego stosowania nawozów w rolnictwie pogarsza się jakość wody w skali całego świata. Niestety, jak większość krajów, Algieria doświadcza ostrego kryzysu środowiskowego połączonego z kurczeniem się zasobów wodnych. Równina na zachód od miasta Annaba jest szczególnie podatna na zanieczyszczenia przemysłowe. Problemy środowiskowe rozpoczęły się dopiero w roku 1980, kiedy to kryzys ekonomiczny doprowadził niektóre firmy przemysłowe do poświęcenia walorów środowiskowych na rzecz korzyści produkcyjnych. Obiektem szczególnego zainteresowania w niniejszej pracy były powierzchniowe poziomy wodonośne i uedy, tj.: Boudjemaâ, Bouhdid, Sidi Harb i Forcha, których wody są często wykorzystywane do nawodniania okolicznych pól. Porównanie wyników z lat 2006-2016 w odniesieniu do: $E C, \mathrm{pH}, \mathrm{Ca}^{2+}, \mathrm{Mg}^{2+}, \mathrm{Cl}^{-}, \mathrm{NO}_{2}$ i z $2006-2010$ w odniesieniu do: $\mathrm{Fe}, \mathrm{Cr}, \mathrm{Cu}^{2+}, \mathrm{Pb}^{+}$ujawniło pogorszenie jakości wody tego regionu, który reprezentuje obszary bardzo podatne na zagrożenie wód podziemnych na zanieczyszczenia.

Słowa kluczowe: degradacja, jakość wody, równina na zachód od Annaby 